\title{
MIĘDZYWYDZIAŁOWY ZAKŁAD BADAŃ NAD ANTYKIEM CHRZEŚCIJAŃSKIM KUL JAKO PROPAGATOR MYŚLI WCZESNOCHRZEŚCIJAŃSKIEJ W POLSCE (w 30-lecie działalności)
}

30 lat mija od chwili, kiedy to najpierw 18 kwietnia Senacka Komisja d/s Nauki, a następnie 13 maja 1969 roku Senat Akademicki KUL powołał do istnienia Międzywydziałowy Zakład Badań nad Antykiem Chrześcijańskim. Główną twórczynią tej naukowej instytucji była przybyła z Wilna do Lublina, po krótkim pobycie na Uniwersytecie Mikołaja Kopernika w Toruniu, filolog klasyczny prof. Leokadia Małunowiczówna, wykładowca literatury łacińskiej późnego antyku na Sekcji Filologii Klasycznej KUL. Ona to kierując się pragnieniem realizowania posoborowego hasła powrotu do źródeł chrześcijaństwa, już w połowie lat 60-tych obmyśliła projekt tej instytucji, a następnie przedstawiła swoje plany i możliwość ich urzeczywistnienia ówczesnemu przewodniczącemu Komisji Episkopatu d/s Nauki Katolickiej ks. kard. Karolowi Wojtyle, który nie tylko uznał celowość erygowania takiego ośrodka naukowego, ale udzielił swego błogosławieństwa i obiecał pomoc materialną. Poparcie tego Autorytetu, liczącego się uczestnika Soboru Watykańskiego II, widzącego w powrocie do wczesnochrześcijańskich źródeł odnowę teologii, który później przyczynił się również do powstania Sekcji Patrystycznej, miało wyjątkowo duże znaczenie. Niemałym wsparciem w realizacji projektu erygowania takiego zakładu był również przybyły z Francji jezuita o. doc. dr hab. Jan Maria Szymusiak, który w 1967 r. został kierownikiem katedry patrologii na Wydziale Teologicznym. Z nim to wspólnie prof. Małunowiczówna, przy wydatnej pomocy ówczesnego dziekana Wydziału Nauk Humanistycznych ks. doc. Władysława Smolenia, opracowała ramowy projekt oraz regulamin przyszłej placówki badawczej, a następnie mimo wielu przeszkód i oporów niektórych czynników uniwersyteckich, zwróciła się w grudniu 1968 roku do Senatu KUL z prośbą o utworzenie międzywydziałowego zakładu, poświęconego badaniom antyku chrześcijańskiego; zakład ten miał prowadzić swą działalność w trzech kierunkach: naukowobadawczym, naukowo popularyzacyjnym i dydaktycznym ${ }^{1}$. W swojej działalnoś-

1 Por. A. Malinowski, 10-lecie Międzywydziatowego Zaktadu Badań nad Antykiem Chrześcijańskim, RTK 26(1979) z. 4, 7-15; S. Longosz, Międzywydziałowy Zakład Badań nad Antykiem 
ci miał podlegać bezpośrednio Rektorowi i Senatowi KUL, przed którymi miał składać coroczne sprawozdania. Rektor również miał powoływać kierownika Zakładu, a także wyrażać bezpośrednio zgodę na zatrudnianie pracowników.

\section{STRUKTURA ZAKŁADU}

1. Kierownictwo Zakładu. Senat KUL erygując 13 V 1969 r. Międzywydziałowy Zakład Badań nad Antykiem Chrześcijańskim i zatwierdzając przedstawiony regulamin, powołał również na wniosek ówczesnego rektora ks. prof. dra hab. Wincentego Granata pierwsze kierownictwo Zakładu. Pierwszym jego kierownikiem został ks. doc. dr hab. Jan Maria Szymusiak, a jego zastępcą prof. Leokadia Małunowiczówna. Po 2 latach, po bezpowrotnym wyjeździe ks. J.M. Szymusiaka za granicę, kierownikiem Zakładu od r. 1971 do r. 1980 była prof. Leokadia Małunowiczówna, a jej zastępcą - doc. Barbara Filarska. Po śmierci prof. L. Małunowiczówny 1 V 1980 r. trzecim kierownikiem Zakładu do r. 1991 była prof. Barbara Filarska, a jej zastępcą od 22 IV 1986 r. został ks. dr Stanisław Longosz. Czwartym wreszcie kierownikiem Zakładu od 28 VI 1991 r., mianowanym przez rektora ks. prof. dra hab. Stanisława Wielgusa, i pełniącym do chwili obecnej tę funkcję jest ks. Stanisław Longosz.

Tuż po erygowaniu Zakładu, w czerwcu 1969 roku odbyło się pierwsze wewnętrzne spotkanie kierownictwa $z$ okazującymi wówczas zainteresowanie antykiem chrześcijańskim osobami. Warto dziś przypomnieć ich nazwiska: ks. mgr L. Gładyszewski, ks. mgr M. Macioszek, ks. mgr Z. Trojnar, ks. mgr E. Łomnicki, s. mgr Jadwiga Kalinowska, ks. S. Szmidt, ks. dr H. Wójtowicz, ks. mgr W. Wójcik, ks. dr A. Bober, ks. dr W. Kania, ks. S. Longosz, ks. dr Sz. Pieszczoch, doc. A. Rodziński, doc. E. Zwolski, ks. doc. J.M. Szymusiak, doc. L. Małunowiczówna, doc. B. Filarska, ks. F. Drączkowski, mgr M. Kaczmarkowski i J. Krzemiński.

2. Pracownicy Zakładu. Liczba osób zatrudnionych etatowo w Międzywydziałowym Zakładzie Badań nad Antykiem Chrześcijańskim należała zawsze do najmniejszych w porównaniu do analogicznych tego typu naukowych placówek uniwersyteckich. Władze uniwersyteckie godziły się na zatrudnienie w nim pracowników najpierw na jednym etacie, potem na dwóch, następnie na trzech, z kolei przez kilkanaście lat na dwóch i pół, by wreszcie wrócić do trzech etatów. W ciągu 30 lat pracowały w Zakładzie następujące osoby:

1. mgr Danuta Szumska od 1969 do czerwca 1974 roku,

2. mgr Maria Kosiarska od 1 IX 1970 r. do końca 1973 roku,

Chrześcijańskim, w: Księga Pamiątkowa w 75-lecie Katolickiego Uniwersytetu Lubelskiego. Wkład w kulturę polskq w latach 1968-1993, red. M. Rusecki, Lublin 1994, 604-610. 
3. mgr Jan Krzemiński od stycznia 1974 do kwietnia 1977 roku,

4. mgr Ewa Tatar-Próchniak od sierpnia 1977 do grudnia 1995 roku,

5. mgr Andrzej Malinowski od grudnia 1977 do września 1983 roku,

6. ks. dr Stanisław Longosz od października 1980 roku $\rightarrow$

7. dr Alicja Stępniewska od lutego 1982 roku $\rightarrow$

8. ks. mgr Antoni Pławecki od września 1984 do grudnia 1985 roku,

9. mgr Barbara Poniatowska od lipca do grudnia 1987 roku, na pół etatu,

10. ks. dr Bazyli Degórski OSPPE od października 1987 do grudnia 1989 roku, na pół etatu,

11. ks. mgr Zbigniew Wójtowicz od stycznia 1996 do czerwca 1997 roku, na pół etatu,

12. mgr Paweł Woźniak od września 1997 do grudnia 1999 roku, na pół etatu,

13. ks. lic. Józef Figiel SDS od lutego 2000 roku $\rightarrow$

3. Biblioteka Zakładu. Ważnym i niezbędnym składnikiem Zakładu jako ośrodka naukowego jest jego specjalistyczna biblioteka, która po 30 latach istnienia tej instytucji osiągnęła liczbę 3070 pozycji, pochodzących początkowo z darów krajowych i zagranicznych. Wśród ofiarodawców zagranicznych figurują takie postacie jak: kard. M. Pellegrino, dyrektor wydawnictwa Sources Chrétiennes C. Mondésert, p. Wanda Gawrońska i prowadzone przez nią Centro Incontri e Studi Europei w Rzymie, prof. A. Hamman, prof. A.M. Malingrey, czy też prof. G. Sanders z Gandawy; w Polsce m.in. ks. prof. F. Blachnicki, ks. dr A. Bober, a ostatnio ks. prof. M. Starowieyski, czy też Biblioteka Uniwersytecka KUL, która chętnie dzieliła się i dzieli z Zakładem swoimi dubletami. Każdy wyjazd za granicę prof. L. Małunowiczówny owocował paczkami książek wyżebranych tam przez nią w różnych bibliotekach, wydawnictwach, księgarniach czy też u osób prywatnych. Będąc przez 5 lat na studiach w Rzymie zarówno sam z odpowiednim polecającym listem, jak i kilkakrotnie wspólnie $\mathrm{z}$ nią chodziliśmy po różnych rzymskich wydawnictwach i księgarniach, gdzie prosiliśmy dla nowo powstałego w Polsce centrum patrystycznego o książki, które potem różnymi sposobami przesyłałem do Lublina. Obecnie księgozbiór Zakładu powiększa się rocznie o ok. 150 nowych pozycji, pochodzących albo z zakupu, albo z darów przesyłanych przez różnych autorów z całej Polski. Są w nim podstawowe patrystyczne serie źródłowe (aczkolwiek niepełne) i tłumaczeniowe, a przede wszystkim wiele opracowań, głównie obcojęzycznych. Brakujące w Zakładzie patrystyczne czasopisma, źródła, tłumaczenia lub opracowania znajdujemy prawie zawsze w znajdującej się tuż za ścianą Bibliotece Uniwersyteckiej, zwłaszcza w jej Czytelni Teologicznej.

4. Lokal. Innym zagadnieniem jest lokalizacja Zakładu, która mimo 30 lat jego działalności po dziś dzień nie została w pełni rozwiązana i pozostaje nadal 
bolesnym problemem. Początkowo Zakład został zlokalizowany we wschodnim baraku KUL w salce o powierzchni $20 \mathrm{~m}^{2}$, potem w maju $1974 \mathrm{r}$. przeniesiono go do gmachu Biblioteki Uniwersyteckiej KUL, gdzie umieszczono go w salce nr 46 (dziś punkt usług kserokopiarskich) o powierzchni $8 \mathrm{~m}^{2}$, a jego księgozbiór przechowywano w szafach na korytarzu piętro niżej; potem we wrześniu 1977 r. przeniesiono go znowu do równie małej salki nr 14 na półpiętrze tejże Biblioteki, gdzie również nie można było rozłożyć z trudem zebranego księgozbioru; wreszcie w r. 1981 przeniesiono go do sąsiedniego budynku obok Biblioteki, gdzie do dziś zajmuje jedną niewielką salę z przedpokojem (nr 5A) o łącznej powierzchni $34 \mathrm{~m}^{2}$, z dobudowaną dopiero w ostatnim roku ubikacją. W tym to jednym pokoju mieści się aktualnie zarówno Zakład ze swym specjalistycznym księgozbiorem, jak i redakcja „Vox Patrum” z trzema pracownikami.

\section{ZADANIA ZAKŁADU}

Nowo powołany Zakład miał w swym założeniu wypełniać od początku kilka przewidzianych w zatwierdzonym regulaminie zadań:

1. koordynować badania nad antykiem chrześcijańskim w Polsce,

2. prowadzić i uporządkować dotychczas wykonywane prace tłumaczeniowe pism Ojców Kościoła,

3. wznowić badania nad archeologią i sztuką wczesnochrześcijańską,

4. opracować polską bibliografię patrystyczną,

5. podjąć badania semantyczne $\mathrm{z}$ zakresu ewolucji pojęć w języku chrześcijańskim, czyli nad tzw. voces,

6. nawiązać współpracę i kontakty z analogicznymi naukowymi ośrodkami polskimi i zagranicznymi,

7. popularyzować różnymi sposobami myśl Ojców Kościoła w Polsce.

Ad. 1. Koordynację polskich badań nad antykiem chrześcijańskim prowadził Zakład przede wszystkim poprzez organizowanie ogólnopolskich, dotąd w tej dziedzinie nieznanych sympozjów, które miały polskich badaczy nie tylko dokształcać, ale przede wszystkim ułatwić im spotkanie się i wzajemne poznanie, nawiązanie kontaktów i wymianę doświadczeń. Tego rodzaju organizowane sympozja były przez długi czas jedyną w Polsce platformą, na której mogli się spotykać patrologowie oraz inni świeccy i duchowni różnego rodzaju badacze problematyki starożytnego chrześcijaństwa. Trzeba pamiętać, że nie było jeszcze w tym czasie Sekcji Patrystycznej, która zresztą powstała (w 1977 r.) na jednym z tego rodzaju sympozjów w Lublinie, a istniejąca od 1954 r. Katedra Patrologii ATK i Katedra Patrologii KUL nie miały możliwości organizowania takich spotkań. W ciągu 30 lat swego istnienia Zakład zorganizował aż 30 
ogólnopolskich, przeważnie dwudniowych sympozjów, podczas których wygłoszono 363 prelekcje w formie dłuższych referatów lub komunikatów, nierzadko z udziałem prelegentów zagranicznych. Sześć z tych spotkań poświęconych było różnym zagadnieniom tłumaczenia pism starożytnych, zwłaszcza wczesnochrześcijańskich, a większość pozostałych jakiemuś wybranemu tematowi ${ }^{2}$; trzy z nich odbyły się w pałacu ks. kard. Karola Wojtyły (13-14 II 1970; 26-27 V 1971; 12-13 II 1974) w Krakowie, który nie tylko je opłacał, ale w większości obrad osobiście uczestniczył; innym razem (31 V - 2 VI 1976) zorganizowane w Metropolitalnym Seminarium Duchownym w Krakowie w całości opłacił, a także pieniężnymi lub materialnymi datkami na ręce prof. L. Małunowiczówny kilkakrotnie wspierał. A oto szczegółowy wykaz zorganizowanych przez Zakład sympozjów:

1) 15 XII 1969 (Lublin) - 3 prelekcje o antyku chrześcijańskim w ogóle,

2) 13-14 II 1970 (Kraków, pałac ks. Kardynała) - 6 prelekcji o różnorodnej tematyce wczesnochrześcijańskiej,

3) 8-9 V 1970 (Warszawa, 00. Jezuici): tłumaczeniowe -5 prelekcji,

4) 5-6 XI 1970 (Lublin): tłumaczeniowe -5 prelekcji,

5) 24-25 II 1971 (Lublin): tłumaczeniowe -6 prelekcji,

6) 21-22 IV 1971 (Lublin): thumaczeniowe -6 prelekcji,

7) 26-27 V 1971 (Kraków, pałac ks. Kardynała): tłumaczeniowe - 7 prelekcji,

8) 3-4 XI 1971 (Włocławek, WSD): tłumaczeniowe -8 prelekcji,

9) 16-17 III 1972 (Lublin): tematyka wczesnochrześcijańska - 6 prelekcji,

10) 25-26 V 1972 (Gniezno, WSD): tematyka wczesnochrześcijańska z udziałem 2 prelegentów zagranicznych -7 prelekcji ${ }^{3}$,

11) 23-24 V 1973 (Lublin): Archeologia i ikonografia wczesnochrześcijańska -7 prelekcji,

12) 12-13 II 1974 (Kraków, pałac ks. Kardynała): Stan polskich badań nad patrologiq i archeologiq chrześcijańskq - 10 prelekcji,

13) 30-31 V 1974 (Wągrowiec): Chrzest w okresie patrystycznym - 5 prelekcji,

14) 5-6 V 1975 (Lublin): Eucharystia w okresie patrystycznym - 8 prelekcji,

15) 31 V - 2 VI 1976 (Kraków, Metropol. Sem. Duch.): Świętość i kult swiętych $w$ okresie patrystycznym - 13 prelekcji,

16) 31 V - 2 VI 1977 (Lublin): Pielgrzymki w starożytności chrześcijańskiej -9 prelekcji ${ }^{4}$,

${ }^{2}$ Szczegółowy wykaz wygłoszonych prelekcji pierwszych 16 sympozjów por. Malinowski, 10-lecie Międzywydziałowego Zakładu, s. 9-15.

${ }^{3}$ Por. J. Krzemiński, W Gnieźnie o starożytności chrześcijańskiej, TP 26(1972) nr 29, s. 7.

${ }^{4}$ Kilka prelekcji z tego i poprzedniego sympozjum opublikowano w RTK $26(1979)$ z. 4 , 73-135. 
17) 19-21 X 1978 (Tarnów, WSD, łącznie z Sekcją Patrystyczną i Katedrą Patrologii ATK): Modlitwa starożytnych chrześcijan - 35 prelekcji ${ }^{5}$,

18) 15-17 V 1979 (Lublin): Św. Bazyli w 1600 rocznicę śmierci - 15 prelekcji

19) 16-19 X 1979 (Lublin): Relacje między architekturq a liturgiq w IV i $V$ wieku - 22 prelekcje,

20) 12-13 III 1981 (Lublin): Św. Jan Chryzostom; Archeologia wczesnochrześcijańska-11 prelekcji ${ }^{7}$,

21) 24-25 XI 1983 (Lublin): Rodzina i matżeństwo w starożytności chrześcijańskiej-19 prelekcji ${ }^{8}$,

22) 21 V 1984 (Lublin): Św. Damazy w 1600 rocznicę śmierci $i$ kard. J. Daniélou w 10 rocznicę śmierci - 3 prelekcje9,

23) 24-25 IV 1987 (Lublin): Św. Augustyn w 1600 rocznice chrztu 23 prelekcje $^{10}$,

24) 18 X 1988 (Lublin): Katecheza patrystyczna w 1600 rocznice śmierci Cyryla Jerozolimskiego - 11 prelekcji ${ }^{11}$,

25) 29-30 X 1991 (Lublin): Kapłaństwo w starożytności chrześcijańskiej 30 prelekcji $^{12}$,

26) 27-28 X 1992 (Lublin): Praca charytatywna w starożytności chrześcijańskiej- 29 prelekcji $^{13}$,

27) 23-24 XI 1995 (Lublin): Symbol Apostolski w nauce i sztuce Kościoła pierwszego tysiąclecia - 12 prelekcji ${ }^{14}$,

5 Wszystkie materiały opublikowano w „Tarnowskie Studia Teologiczne” 8(1981) ss. 368; rec. A. Bober, VoxP 1(1981) z. 1, 69-72,

${ }^{6}$ Por. A. Malinowski, Sympozjum bazyliańskie $w$ Lublinie, VoxP 2(1982) z. 3, 422-425; materiały zaś opublikowano częściowo w RTK 27(1980) z. 4 i w VoxP 2(1982) z. 4.

7 Por. A. Malinowski, Kolokwium patrystyczno-archeologiczne w Lublinie, VoxP 1(1981) z. 1, 54-57.

${ }^{8}$ Por. sprawozdanie M. Marczewski, Rodzina w Kościele starożytnym, VoxP 3(1983) z. 5 , 489-494; materiały opublikowano w całości w VoxP 5(1985) z. 8-9, 7-364, 443-508.

${ }^{9}$ Por. A. Stępniewska, Sympozjum damazjańskie, VoxP 4(1984) z. 6-7, 460-465; S. Longosz, Papież Damazy jako obrońca czystości wiary, tamże 208-230.

${ }^{10}$ Por. szczegółowy wykaz prelekcji VoxP 6(1986) z. 10, 393-394; sprawozdanie J. Grzywaczewski, Św. Augustyn w 1600 rocznicę chrztu, VoxP 7( 1987) z. 12-13, 499-503; materiały opublikowano w VoxP 8(1988) z. 14, 7- 460.

11 Por. szczegółowy wykaz prelekcji VoxP 8(1988) z. 14, 495-496; sprawozdanie A. Swoboda, Sympozjum o katechezie patrystycznej, VoxP 8(1988) z. 15, 1119-1124; materiały opublikowano w VoxP 10(1990) z. 18, 55-156.

${ }^{12}$ Materialy opublikowano w VoxP 13-15(1993-1995) z. 24-29, 29-311, 499-556; sprawozdanie S. Longosz, Kapłaństwo w starożytności chrześcijańskiej, tamże s. 639-645.

${ }^{13}$ Por. sprawozdanie J. Grzywaczewski, Praca charytatywna w starożytności chrześcijańskiej, VoxP 11-12(1991-1992) z. 20-23, 539-542; lub S. Longosz, ,Przegląd Uniwersytecki KUL” 5(1993) nr 1(21) s. 12 i 24; materiały opublikowano w VoxP 16(1996) z. 30-31, 49-336, 493-510.

14 Por. szczegółowy wykaz tematów VoxP 11-12(1991-1992) z. 20-23, 569-570; sprawozdanie A. Stępniewska, Symbol Apostolski w nauce i sztuce starożytnego Kościoła, VoxP 13-15(1993- 
28) 25-26 XI 1997 (Lublin): Św. Ambroży w 1600 rocznicé śmierci 20 prelekcji $^{15}$

29) 25-26 V 1999 (Lublin): Polskie studia nad antykiem chrześcijańskim 21 prelekcji $^{16}$.

Wszystkie wyżej wymienione sympozja miały zawsze charakter otwarty, brali w nich udział ludzie z całej Polski, specjaliści i sympatycy różnych dziedzin starożytności chrześcijańskiej, świeccy i duchowni, katolicy, prawosławni i protestanci, wierzący i niewierzący, a łączyło ich jedno - zainteresowanie antykiem chrześcijańskim. Spotkania te dostarczały polskim badaczom problematyki wczesnochrześcijańskiej możliwości poznania się, wymiany doświadczeń, wzajemnego poinformowania się o tłumaczonych tekstach Ojców Kościoła i podejmowanych inicjatywach wydawniczych, a niekiedy także osobistego poznania przybyłych prelegentów zagranicznych.

W związku z ciągle trudną sytuacją finansową KUL, Zakład otrzymywał bardzo małe dotacje od uczelni, głównie na książki i tylko organizacyjne koszty sympozjów (bez płacenia honorariów za wygłoszone prelekcje); sympozja więc w latach początkowych mogły być organizowane w większości dzięki dotacjom osób prywatnych lub Wyższych Seminariów Duchownych, w których się odbywały. Tak wiec cztery sympozja zorganizowane w Krakowie sfinansowane zostały przez ks. kard. Karola Wojtyłę, dwa (w Gnieźnie i Wągrowcu) przez ks. kard. Stefana Wyszyńskiego, dwa inne (we Włocławku i Tarnowie) przez księży biskupów ordynariuszy - ks. bpa J. Zarembę i ks. bpa J. Ablewicza, jedno w Warszawie przez Księży Jezuitów. Pozostałe sympozja organizowane w Lublinie opłacane były $\mathrm{z}$ dotacji KUL, a ostatnio dwa razy (sympozjum o Symbolu Apostolskim i sympozjum o polskich studiach nad antykiem chrześcijańskim) dofinansowane przez Komitet Badań Naukowych.

Do uczestników niektórych sympozjów kierowane były niekiedy listownie lub telegraficznie słowa życzeń i uznania najwyższych władz kościelnych. Tak na przykład uczestnikom sympozjum obradującego na temat chrztu wczesnochrześcijańskiego w Wągrowcu ks. kard. Stefan Wyszyński życzył:

„Uczestnikom jubileuszowego Sympozjum organizowanego przez zakład Badań nad Antykiem Chrześcijańskim przy KUL w piątą rocznicę jego działalności przesyłam najlepsze życzenia, by wspólne gromadzenie się dla naukowej refleksji nad Sakramentem Chrześcijańskiego Wtajemniczenia w zaraniu dziejów Kościoła, który nieprzerwanie pulsuje Życiem i Prawdą Bożą wnoszoną w świat współczes-

1995) z. 24-29, 684-691; materiały opublikowano oddzielnie: Symbol Apostolski w nauczaniu i sztuce Kościoła do Soboru Trydenckiego, red. R. Knapiński, Lublin 1997, 11-235.

15 Por. sprawozdanie S. Longosz, Sympozjum ambrozjańskie w KUL, VoxP 17(1997) z. 32-33, 595-602; materiały opublikowano w VoxP 18(1998) z. 34-35, 7-273, 471-510, 575-606.

${ }^{16}$ Por. szczegółowy wykaz prelekcji VoxP 18(1998) z. 34-35, 684-685; wprowadzenie VoxP 17(1997) z. 32-33, 611-612. 
ny, było nie tylko bodźcem do wnikliwych i dogłębnych badań naukowych, ale i pozwoliło z większym zrozumieniem dostrzegać wartości niezniszczalne. Życzę jednocześnie, żeby pobyt w Domu im. Ks. Jakuba Wujka w Wągrowcu pozwolił też - za wzorem Wielkiego Thumacza Biblii - na uświadomienie sobie, jak wspaniale zawsze ukazuje się chrześcijaństwo, gdy jest pojmowane jako religia Słowa Żywego i religia Księgi Życia. Wszystkim Uczestnikom Sympozjum oraz ich pracy serdecznie błogosławię".

Zaproszony do Tarnowa na sympozjum o tematyce Modlitwa starożytnych chrześcijan ks. kardynał Karol Wojtyła przeszkodzony wyjazdem na konklawe pisał 2 X 1978 roku:

„Pragnę serdecznie podziękować za zaproszenie mnie do wzięcia udziału w sympozjum patrystycznym na temat: Modlitwa starożytnych chrześcijan, organizowanym przez Sekcję Patrystyczną przy Komisji Episkopatu Polski ds. Nauki Katolickiej, Międzywydziałowy Zakład Badań nad Antykiem Chrześcijańskim KUL oraz Katedrę i Zakład Patrologii ATK. Niestety w sympozjum tym nie wezmę udziału ze względów dobrze znanych: niespodziewana śmierć Ojca św. Jana Pawła I i mające się odbyć konklawe.

Jeśli idzie o samo sympozjum, to pragnę wyrazić me głębokie zadowolenie z tematu obrad. Problem modlitwy jest zawsze bardzo ważny w życiu Kościoła. Dzisiaj nabiera on szczególniejszej aktualności w związku z jej coraz większym niedocenianiem przez współczesnych ludzi. Sądzę, że pogłębiona refleksja nad modlitwą starożytnych chrześcijan przez polskich badaczy okresu patrystycznego może stanowić cenny wkład do jej dowartościowania w świadomości Ludu Bożego.

Jako Przewodniczący Komisji Episkopatu ds. Nauki Katolickiej wyrażam radość, że świeżo ukonstytuowana Sekcja Patrystyczna uczestniczy czynnie w zorganizowaniu sympozjum. Wszyscy odczuwaliśmy potrzebę jej istnienia i jestem przekonany, że w przyszłości dobrze przysłuży się ona do rozwoju studiów patrystycznych na terenie całego kraju, włączając w zakres swojej działalności dydaktyczno-naukowej wszystkich wykładowców i profesorów patrologii Uczelni Katolickich oraz Wyższych Seminariów Duchownych tak diecezjalnych, jak i zakonnych.

Proszę przyjąć szczere życzenia błogosławieństwa Bożego i owocnych obrad."

Telegram zaś Ojca Świętego Jana Pawła II do uczestników sympozjum zorganizowanego z okazji 30-lecia powołania Zakładu, umieściliśmy na początku tego tomu „Vox Patrum”.

Zakład nie ograniczał nigdy swej działalności wyłącznie do własnego środowiska lubelskiego, ale czuł się zawsze własnością wszystkich polskich badaczy antyku chrześcijańskiego, z nimi współpracował, w miarę możności naukowo ich wspomagał, a bardziej zasłużonych honorował Księgami Pamiątkowymi, którymi były specjalne tomy „Vox Patrum”. W ciągu 30 lat swego istnienia zakład uhonorował Księgami Pamiątkowymi aż 6 następujących osób, zasłużonych w dziedzinie polskich badań nad antykiem chrześcijańskim: 
w 1984 roku ks. dra Andrzeja Bobera SJ: 6-7 tom „Vox Patrum” w 1987 roku ks. dra hab. Wojciecha Kanię: 12-13 tom „Vox Patrum” w 1989 roku ks. dra hab. Wacława Eborowicza: 15 tom „Vox Patrum” w 1990 roku ś.p. ks. dra hab. Jana M. Szymusiaka: 16 tom „Vox Patrum” w 1995 roku p. prof. dra hab. Barbarę Filarską: 20-23 tom „Vox Patrum” w 1999 roku ks. prof. dra hab. Emila Stanulę: 32-33 tom „Vox Patrum”

\section{Ad 2. Zakład pomagał uporządkować akcję tłumaczeniową pism Ojców} Kościoła i sam rozpoczął wydawanie nowej serii o charakterze antologicznym „Starożytne Teksty Chrześcijańskie” (STCh), która oprócz polskiego przekładu w pierwotnych zamierzeniach miała również zawierać tekst oryginalny. Dotąd istniała tylko poznańska seria „Pisma Ojców Kościoła”, która po ukazaniu się 25 tomów powoli zamierała, w Wydawnictwie PAX wydano po wojnie do r. 1969 ponad 10 przekładów patrystycznych nie ujętych w żadną serię, a w Warszawie na ATK miały się ukazać pierwsze tomy serii „Pisma Starochrześcijańskich Pisarzy”, głównie w oparciu o zachowane nie publikowane przekłady o. Władysława Szołdrskiego. Profesor L. Małunowiczówna chciała ożywić tę akcję tłumaczeniową, przygotować tłumaczy tekstów wczesnochrześcijańskich, czemu miało m.in. służyć aż 6 zorganizowanych sympozjów, poświęconych różnorodnym problemom przekładania tekstów starożytnych. Zachęcała też do tego, by na zwoływanych sympozjach tłumacze w specjalnie wyznaczonym czasie wzajemnie się informowali o prowadzonych lub planowanych przekładach, by nie dublować tłumaczenia tych samych tekstów. Widząc zaś cieszące się dużą popularnością na Zachodzie wszelkiego rodzaju antologie, zaczęła wydawać w Zakładzie nową patrystyczną serię o charakterze antologicznym: „Starożytne Teksty Chrześcijańskie”. Dotąd ukazały się w tej serii trzy tomy:

Wybór homilii i kazań na święta Pańskie i Maryjne (z dołączonym oryginalnym tekstem łacińskim), red. L. Gladyszewski, Lublin 1976.

Antologia listu starochrześcijańskiego, cz. I: Listy z dziedziny kierownictwa duchowego, red. L. Małunowiczówna, Lublin 1978.

Antologia modlitwy wczesnochrześcijańskiej, red. L. Gładyszewski, Lublin 1993.

Kolejnymi przewidzianymi tomami tej serii są opracowywane:

Antologia tekstów o kapłaństwie wczesnochrześcijańskim, red. S. Longosz.

Antologia inskrypcji wczesnochrześcijańskich, w wyborze i przekładzie L. Małunowiczówny.

Ad. 3. Wzbudzenie działalności archeologii wezesnochrześcijańskiej. Antyk chrześcijański to nie tylko literatura, ale również starożytne pomniki materialne i wykopaliska, którymi zajmuje się archeologia. Tymczasem do końca lat sześćdziesiątych nie było w Polsce nigdzie żadnej działającej katedry arche- 
ologii wczesnochrześcijańskiej; wspominano tylko dawnych polskich archeologów w osobach ks. abpa Józefa Bilczewskiego, ks. Antoniego Kwiecińskiego, czy Pawła Stygera, a działalność na tym polu ograniczono do kilku sporadycznych wykładów o katakumbach czy sarkofagach w ramach historii Kościoła. Chodziło teraz o wzbudzenie większego zainteresowania tą dziedziną. Zadania zorganizowania systematycznych uniwersyteckich studiów $\mathrm{z}$ archeologii i sztuki wczesnochrześcijańskiej podjęła się m. in. wyhabilitowana w 1967 roku doc. Barbara Filarska, najpierw zastępca kierownika, a od roku 1980 kierownik Międzywydziałowego Zakładu Badań nad Antykiem Chrześcijańskim; chodziło o zorganizowanie tego rodzaju studiów przede wszystkim w KUL i ATK ${ }^{17}$. Dla wzbudzenia większego zainteresowania tą problematyką, Zakład zorganizował w Lublinie trzy specjalne sympozja (XI, XIX i XX) poświęcone tematyce archeologicznej:

23-24 V 1973 roku: Archeologia i ikonografia wczesnochrześcijańska 7 prelekcji,

13-19 X 1979 roku: Relacje między architektura a liturgia IV i V wieku 22 prelekcje,

11-12 III 1981 roku: Św. Jan Chryzostom oraz archeologia chrześcijańska5 prelekcji archeologicznych.

Również w programach pozostałych sympozjów prawie zawsze umieszczano 1 - 2 prelekcji o tematyce archeologicznej, jak na przykład podczas X sympozjum (25-26 V 1972, Gniezno): doc. T. Dobrzeniecki - Przedstawienie Chrystusa w sztuce starochrześcijańskiej; podczas XII sympozjum (12-13 II 1974, Kraków): doc. B. Filarska - dr T. Górski - Archeologia chrześcijańska; podczas XIII sympozjum (30-31 V 1974, Wągrowiec): doc. Dobrzeniecki - Chrzest w typologii sztuki wczesnochrześcijańskiej; podczas XIV sympozjum (5-6 V 1975, Lublin): prof. G. Sanders - L'Eucharistie et les inscriptions latines paleochrétiennes, mgr T. Gołgowski - Architektura a liturgia Eucharystii w Nubii i Egipcie; podczas XV sympozjum (31 V - 2 VI 1976, Kraków): prof. V. Saxer - Le culte des martyrs en Afrique du Ile au VIe siècle, doc. B. Filarska - Miejsca kultu męczenników, doc. T. Dobrzeniecki - Wybrane zagadnienia z ikonografii świętych w sztuce wczesnochrześcijańskiej, mgr B. Rostkowska - Święci w sztuce nubijskiej; podczas XVI sympozjum (31 V - 2 VI 1977, Lublin): prof. A. Sadurska - Sanktuarium Fortuny Primigenii w Praeneste, doc. T. Dobrzeniecki - Ruch pielgrzymkowy a ikonografia wczesnochrześcijańska, mgr T. Gołgowski - Sanktuarium św. Menasa k. Aleksandrii; podczas XVII sympozjum (19-21 X 1978, Tarnów): prof. A. Sadurska - Pietas w sztuce cesarstwa rzymskiego, mgr B. Wronikowska - Problem motywu oranta w sztuce wczesnochrześcijańskiej; podczas XXIII sympozjum (24-25 IV 1987, Lublin): doc.

${ }^{17}$ Por. B. Filarska, Archeologia chrześcijańska w Ratio studiorum Wyższych Seminariów Duchownych, VoxP 7(1987) z. 12-13, 520-521. 
B. Filarska - Baptysterium w Mediolanie, dr T. Gołgowski - Hippona dziś, mgr E. Tatar-Próchniak - Starożytna ikonografia św. Augustyna; podczas XXV sympozjum (29-30 X 1991, Lublin): dr T. Górski - Starochrześcijańskie kapłaństwo w epigraficznej dokumentacji; podczas XXVII sympozjum (23-24 XI 1995, Lublin): ks. prof. R. Knapiński - Kolegium apostolskie w ikonografii pierwszego tysiąclecia; podczas XXVIII sympozjum (25-26 XI 1997, Lublin): dr J.S. Partyka - Grób, relikwie i kult św. Ambrożego; prof. U. Mazurczak Ikonografia św. Ambrożego w sztuce europejskiej i polskiej. Wybór i typologia przedstawien.

Dla ożywienia tychże zainteresowań Zakład zorganizował w 1975 roku (10 IX - 8 X) wycieczkę naukową patrologów i archeologów poprzez Mediolan, Wenecję i Neapol do Rzymu, gdzie wszyscy uczestniczyli w IX Międzynarodowym Kongresie Archeologii Chrześcijańskiej (21-28 IX), zaznaczając liczny udział Polaków w tej naukowej imprezie. W międzyczasie na zlecenie Zakładu dokonano inwentaryzacji zabytków sztuki wczesnochrześcijańskiej w Muzeum Narodowym w Warszawie (236 pozycji) i Krakowie (Muzeum Czartoryskich, 42 pozycje), a prof. B. Filarska jako kierownik Zakładu opublikowała trzy obszerne i bogato ilustrowane podręczniki do archeologii i sztuki wczesnochrześcijańskiej: Początki architektury chrześcijańskiej (Lublin 1983), Początki sztuki chrześcijańskiej (Lublin 1985), Archeologia chrześcijańska zachodniej części imperium rzymskiego (Warszawa 1999).

W wyniku tych zabiegów i starań, głównie prof. Barbary Filarskiej, w 1971 roku powstaje Katedra Archeologii Chrześcijańskiej na Wydziale Teologicznym ATK, której pierwszym kierownikiem zostaje ks. doc. L. Stefaniak ${ }^{18}$, a później w 1995 roku w wyniku włączenia problematyki archeologii i sztuki wczesnochrześcijańskiej do Katedry Historii Sztuki Starożytnej powstała Katedra Historii Sztuki Starożytnej i Wczesnochrześcijańskiej na Wydziale $\mathrm{Hu}$ manistycznym KUL, której kierownikiem jest aktualnie prof. dr hab. B. Iwaszkiewicz-Wronikowska. W tym to drugim ośrodku pod kierunkiem prof. B. Filarskiej powstało 16 prac magisterskich i 3 doktorskie z dziedziny archeologii i sztuki wczesnochrześcijańskiej ${ }^{19}$, a w roku 1994 także praca habilitacyjna dr B. Iwaszkiewicz-Wronikowskiej - Vestigia christianorum. Świadectwa obecności chrześcijan $w$ Rzymie przedkonstantyńskim. W ten sposób realizuje się powoli zaplanowane w regulaminie Zakładu budzenie w Polsce zainteresowań również archeologią i sztuką wczesnochrześcijańską.

Ad 4. Opracowanie polskiej bibliografii antyku chrześcijańskiego. Warunkiem każdego poważnego prowadzenia badań w jakiejś dyscyplinie jest uświa-

${ }_{18}$ Por. B. Ruszczyc, Studia archeologii chrześcijańskiej w ATK, VoxP 9(1989) z. 16, 360-366.

19 Szczegółowy wykaz magisteriów i doktoratów napisanych pod jej kierunkiem zob. VoxP 11-12(1991-1992) z. 20-23, s. 13 n. 10-11; na ATK s. 14 n. 14. 
domienie sobie tego, co dotychczas w tej dziedzinie już zrobiono. W nawiązaniu do tego Zakład postawił sobie również w regulaminie za cel opracowanie pełnej retrospektywnej bibliografii antyku chrześcijańskiego w Polsce. W związku z tym przeszukano w ramach różnych odpłatnych zajęć zleconych prawie wszystkie czasopisma polskie od połowy XIX do połowy XX wieku znajdujące się w Bibliotece Uniwersyteckiej KUL i w kilku innych większych bibliotekach polskich. W prace nad tego rodzaju bibliografią zaangażowali się szczególnie prof. Janina Czerniatowicz i były etatowy pracownik Zakładu mgr Czesław Mazur. Pierwszym owocem ich żmudnych, ale niewątpliwie pionierskich poszukiwań, był tom I. Recepcji antyku chrześcijańskiego $w$ Polsce. Wiek $X V$-XVIII, którego część 1: Autorzy i teksty została opublikowana przez Wydawnictwo TNKUL w 1978 roku, a część 2: Problemy doktrynalne w 1983 roku. Opracowanie dwóch następnych tomów, obejmujących okres 1800-1995 r. w oparciu o obszerne zebrane już materiały zostało, niestety, przerwane przez śmierć p. Cz. Mazura, a zgromadzone materiały okazały się niedostępne. Swego rodzaju kontynuacją tego przerwanego zadania jest opracowywana przeze mnie, niezależnie od wspomnianych wyżej zgromadzonych prawdopodobnie zaginionych materiałów, Polskojęzyczna bibliografia antyku chrześcijańskiego 1895-1995, którego mała wybrana część w alfabetycznym układzie autorów nowożytnych została opublikowana w I tomie drugiego wydania Patrologii ks. prof. Sz. Pieszczocha (Gniezno 1994, 201-280). Jej publikacja w całości, doprowadzona do roku 2000, w układzie według autorów starożytnych (przekłady, opracowania, prace dyplomowe) przewidziana jest w przyszłym roku. Wyrazem kontynuowania prac nad tego rodzaju bibliografią jest też gromadzona przez ks. dra Naumowicza i mnie oraz publikowana na łamach „Vox Patrum” od roku 1993, coroczna polska bibliografia antyku chrześcijańskiego.

Ad. 5. Podjęcie badań semantycznych z zakresu ewolucji pojęć w języku chrześcijańskim, to kolejne postawione sobie przez Zakład zadanie; chodzi o opracowanie katalogu tzw. „Voces”. Wiele bowiem zarówno greckich jak i łacińskich terminów zmieniło swą treść, czyli semantyczne znaczenie, pod wpływem chrześcijaństwa, tak że nierzadko co innego znaczyły w klasycznym języku pogańskim, a co innego w późniejszym języku chrześcijańskim (np. sacramentum, fides, symbolum itd.). W analitycznych badaniach nad nimi chodzi o ukazanie procesu zmiany znaczenia i ich semantycznej ewolucji. W tego rodzaju badania, zainicjowane na początku XX wieku przez wiele naukowych ośrodków Europy i sygnalizowane regularnie w tomach Bibliographia Patristica, starał się również włączyć nowo powstały Zakład, tym bardziej, że jego założycielka prof. L. Małunowiczówna dzięki swojej pracy De voce „sacramenti" apud S. Hilarium Pictaviensem (Lublin 1956) znała się na tym i potem poprowadziła nawet kilka prac magisterskich $\mathrm{z}$ tej dziedziny. W ramach realizowania tego zadania mgr Maria Kosiarska z Zakładu rozpoczęła przygotowy- 
wanie pełnej bibliografii opracowanych już tego rodzaju voces. Gdy jednak w r. 1980 taką bibliografię opublikował H.J. Sieben (Voces. Eine Bibliographie zu Wörtern und Begriffen aus der Patristik 1918-1978, Berlin-New York 1980, ss. 462), przerwała kwerendę, a swe zbiory liczące kilkaset fiszek, przekazała do archiwum Zakładu, gdzie czekają na dalsze uzupełnienia i kontynuację. Badań tych jednak ani uzupełnień aktualnie w Zakładzie nikt nie prowadzi, choć pewne uzupełnienia, zwłaszcza polskimi pracami, zostały już naniesione w recenzji owych Voces Siebena na łamach „Vox Patrum”20.

\section{Ad. 6. Nawiązanie kontaktów i współpracy $z$ analogicznymi naukowymi} ośrodkami zagranicznymi, głównie przez zapraszanie badaczy zagranicznych, to następne zadanie Zakładu. Zakład pozostawał długo pierwszą i jedyną instytucją w kraju, nawiązującą kontakty z analogicznymi ośrodkami studiów patrystycznych w świecie. Na zaproszenia skierowane przezeń w imieniu Uniwersytetu odwiedziło Polskę w ciągu 30 lat działalności Zakładu 33 wybitnych specjalistów z różnych dziedzin antyku chrześcijańskiego, którzy wygłaszali referaty (najczęściej podczas sympozjów) i dzielili się swoim doświadczeniem. Widnieją wśród nich takie znane nazwiska, jak: O. Montevecchi z Mediolanu (1972), A. Lamiński z Erfurtu (1972), G. Sanders z Gandawy (1974), J.D. Lafontaine z Louvain (1974), A. Hamman, V. Saxer i R. Jacquard - wszyscy z Rzymu (1976), A.M. Malingrey z Lille (1976), G. Lazzati z Mediolanu (1976), M.V. Esbroeck z Brukseli (1977), S. Papadopulos z Aten (1977), C. Mondésert z Lyonu (1977), Albert van Roey z Leuven (1977) i Nicole van der VorstZeegers z Louvain (1977), V. Grossi z Rzymu (1978), J. Christern z Nijmegen (1979), P.A. Fevrier z Aix-en-Provence (1979), M. Scopello ze Strasburga (1978), O. Cracco Ruggini z Turynu (1979), M.C. Diaz y Diaz z Santiago de Compostella (1979), S. Rudberg z Lundu (1980), M.J. Bartelink z Nijmegen (1980), M. Forlin Patrucco z Turynu (1950), J. Freduille z Tuluzy (1980), Ch. Pietri z Paryża (1980), R. Brändle z Bazylei (1981), B. Kytzler z Berlina Zachodniego (1983), N. Cipriani z Rzymu (1987) i C. Riggi z Rzymu (1988), Ph. Régerat z Aix Provence (1997), Enrico Dal Covolo z Rzymu (1997), państwo Michaela i Klaus Zelzerowie z Wiednia (1997). Odwiedzili oni nie tylko Lublin, ale także inne ośrodki naukowe w Polsce. W odpowiedzi na te wizyty również przedstawiciele Zakładu wyjeżdżali od czasu do czasu za granicę, gdzie w analogicznych ośrodkach studiów nad antykiem chrześcijańskim informowali opinię publiczną o polskich pracach i przedsięwzięciach. Tak np. czyniła prof. L. Małunowiczówna na kongresach patrystycznych w Oksfordzie $(1971,1975,1979)$, na międzynarodowych kongresach: archeologii chrześcijańskiej w Rzymie (1972), studiów bazyliańskich w Toronto (1979), studiów ambrozjańskich w Mediolanie (1974), oraz ks. dr S. Longosz na X, XI i XII Kongresie Patrys-

${ }^{20}$ Por. S. Longosz, VoxP 8(1988) z. 15, 117-118. 
tycznym w Oksfordzie $(1987,1991,1995)$ z wygłaszanymi tam komunikatami, a w 1992 roku imiennie zaproszony z ks. prof. Emilem Stanulą jako jedyni wybrani Polacy na międzynarodowe sympozjum zorganizowane w Strasburgu przez Unię Europejską na temat: „Ojcowie Kościoła u źródeł Europy”.

Zakład utrzymuje ponadto stałe kontakty i wymianę informacji z Instytutem Patrystycznym „Augustinianum” w Rzymie, z Instytutem „Sources Chrétiennes" w Lyonie i z Association Canadienne des Études Patristiques w Toronto.

Ad. 7. Popularyzacja myśli Ojców Kościoła w kulturze polskiej, to ostatnie i najważniejsze postawione sobie przez Zakład zadanie. Zakład nie jest placówką dydaktyczną, jakkolwiek jego pracownicy prowadzą niekiedy zajęcia dydaktyczne na wydziałach uniwersyteckich, głównie na filologii klasycznej lub Wydziale Teologicznym. Służył jednak zawsze swą pomocą, zwłaszcza bibliograficzną, badaczom antyku chrześcijańskiego z całej Polski, którzy tu nierzadko przyjeżdżali oraz korzystali z biblioteki i konsultacji. Tutaj w latach 80-tych odbywały swe miesięczne staże m.in. doktorantki prof. J. Jundziłła z WSP w Bydgoszczy - p. mgr Violetta Rączewska i p. mgr Bożena Stawoska, a potem doktorant i asystent prof. T. Kotuli z Uniwersytetu Wrocławskiego p. mgr A. Wypustek (obecnie wszyscy są już doktorami), tutaj bywała p. prof. M. Jaczynowska, p. prof. E. Wipszycka, p. prof. M. Szarmach z UMK z Torunia i kilku innych wybitnych polskich badaczy problematyki starożytnej, tutaj zrodziło się wiele tematów prac magisterskich i doktorskich.

Tematykę wczesnochrześcijańską popularyzowali pracownicy Zakładu także przez pogadanki radiowe. Prof. L. Małunowiczówna (kilka), a potem ja jako przedstawiciel Zakładu wygłosiłem lub przygotowałem do Radia Watykańskiego pod koniec lat 70-tych i na początku lat 80-tych ponad 150 dziesięciominutowych pogadanek do tzw. rubryki ,Z pism Ojców Kościoła” na temat wczesnochrześcijańskiej modlitwy, rodziny, małżeństwa, wychowania dzieci, pokuty, Eucharystii, kapłaństwa, działalności charytatywnej, kultury klasycznej itd. Ponadto w roku 1998 patrologowie lubelscy wygłosili pod patronatem i nazwą Zakładu w Katolickim Radiu Lublin 32 dwudziestominutowe konferencje na temat wszystkich starożytnych doktorów Kościoła ${ }^{21}$.

Problematykę wczesnochrześcijańską propagował również Zakład poprzez organizowane konferencje i sesje. W 1988 roku Zakład zorganizował pod patronatem Towarzystwa Naukowego KUL cykl publicznych wykładów w małej auli KUL na wybrane tematy antyku chrześcijańskiego ${ }^{22}$, które m.in.

${ }^{21}$ Por. J. Grzywaczewski - S. Longosz, Ojcowie Kościoła na falach radiowych, VoxP 17(1997) z. 32-33, 606-608.

${ }^{22}$ Por. S. Longosz, Wyktady publiczne z dziedziny antyku chrześcijańskiego, VoxP 8(1988) z. $14,492-493$. 
wygłaszali: ks. bp prof. J. Śrutwa - W poszukiwaniu grobu św. Piotra (13 I), prof. B. Filarska - Kościót katakumb (17 II), ks. dr S. Longosz-Ojcowie naszej wiary (16 III), dr A. Ziółkowski - Konstantyn Wielki: wyjście chrześcijaństwa z podziemi, ks. doc. M. Starowieyski - Maryja w pierwszych wiekach Kościoła (11 V). Podobnie w ramach działającej od r. 1972 przy Wydziale HistorycznoFilologicznym TNKUL Komisji Badań nad Antykiem Chrześcijańskim ${ }^{23}$ Zakład organizuje comiesięczne (trzeci czwartek miesiąca) spotkania z konferencjami wygłaszanymi przez specjalistów z KUL, UMCS i innych uniwersyteckich ośrodków polskich. W ostatnich latach, w roku 1995/96 odbyło się 6 tego rodzaju naukowych spotkań, w roku 1996/97 - 6 spotkań, w roku 1997/98 6 spotkań, w roku 1998/99 - 7 spotkań, w roku 1999/2000 - 7 spotkañ ${ }^{24}$.

Trzeba tu też wspomnieć organizowane przez pracowników zakładu złożone z 3-4 konferencji wyjazdowe półdniówki patrystyczne, jakie miały miejsce m.in. w roku 1986 w Wyższym Seminarium Duchownym w Tarnowie, a w maju 1989 roku w Wyższym Seminarium Duchownym w Przemyślu.

Najbardziej jednak Zakład popularyzuje tematykę wczesnochrześcijańską poprzez wydawany przez siebie od r. 1981 periodyk „Vox Patrum”, którego (oprócz niniejszego) ukazało się już 35 tomów, łącznie 10216 stron. Dzięki niemu należymy do tych nielicznych państw ( Hiszpania, Holandia, Niemcy, USA, Włochy), które posiadają specjalistyczne czasopismo naukowe, poświęcone wyłącznie problematyce starożytności chrześcijańskiej. Nie ogranicza się ono znów wyłącznie do środowiska lubelskiego, ale jego łamy są otwarte dla badaczy całej Polski. Wielu może dziwi forma i treść pierwszych jego zeszytów, ale trzeba pamiętać, w jakim czasie one powstawały, że był to początkowo „Biuletyn do wewnętrznego użytku”, w którym nie wolno było umieszczać ani artykułów, ani na karcie tytułowej zaznaczać roku czy tomu, by nie zdradzać, że jest to rodzące się czasopismo; z czasem dopiero udoskonalaliśmy jego wygląd i treść. Chcieliśmy, by było to autentyczne „czasopismo”, a nie praca zbiorowa, by zapisywało czas życia patrystycznego, stąd oprócz artykułów dużo w nim recenzji, sprawozdań, bibliografii i informacji. Celowo opóźniamy nieraz wydawanie poszczególnych tomów, by każdy rocznik zawierał cały i pełny obraz życia patrystycznego minionego roku.

O powstaniu tego czasopisma i jego założeniach informowaliśmy opinię publiczną zarówno w Radiu Watykańskim (28 października 1983 r.) ${ }^{25}$, jak

${ }^{23}$ Por. A. Malinowski, Komisja Badań nad Antykiem Chrześcijańskim KUL, VoxP 3(1983) z. 4, 281-286; S. Longosz, Odrodzona Komisja Badań nad Antykiem Chrześcijańskim, VoxP 11-12(1991-1992) z. 20-23, 561-569.

${ }^{24}$ Por. szczegółowy wykaz prelekcji: za rok $1996 / 97$ = VoxP 13-15(1993-1995) z. 24-29, s. 723 ; za rok 1997/98 = VoxP 17(1997) z. 32-33, s. 608; za rok 1998/99 = VoxP 18(1998) z. 34- 35, s. 679; za rok $1999 / 2000=$ tamże s. 685 .

${ }^{5}$ Por. S. Longosz, Wywiad dla Radia Watykańskiego na temat „Vox Patrum”, VoxP 3(1983) z. $5,495-499$. 
i na Międzynarodowym Kongresie Patrystycznym w 1987 r. w Oksfordzie, gdzie periodyk ten był wystawiony wśród najnowszych publikacji patrystycznych, a każdy z 800 uczestników kongresu otrzymał wśród różnych informacji o nowych Instrumenta studiorum także obszerną notatkę: „Vox Patrum” - eine neue patristische Zeitschrift ${ }^{26}$. Cztery pierwsze zeszyty zostały także wręczone Ojcu św. Janowi Pawłowi II 23 października 1983 r. w Rzymie ${ }^{27}$. Każdy z zeszytów zawiera 5 zasadniczych działów: Dokumenty Nauczycielskiego Urzędu Kościoła (ich polskie przekłady) na temat Ojców lub różnych rocznic starożytności chrześcijańskiej (jest to oryginalna cecha naszego patrystycznego czasopisma), Artykuły, Przekłady (niewielkich pism patrystycznych nie mieszczących się w seriach), Recenzje oraz Dział informacyjny (sprawozdania, bibliografie osobowe, bieżące lub tematyczne, zapowiedzi wydawnicze, nekrologi, informacje z życia patrystycznego oraz coroczną patrystyczną zawartość polskich i zagranicznych czasopism Biblioteki Uniwersyteckiej KUL).

Jego odbiorcami oprócz osób prywatnych duchownych i świeckich są także wszystkie biblioteki wyższych seminariów duchownych i zakonnych, wiele bibliotek klasztornych oraz wszystkie polskie ośrodki uniwersyteckie zajmujące się starożytnością. Ponadto jest on wysyłany w ok. 50 egzemplarzach przez Zakład lub Bibliotekę Uniwersytecką w drodze wymiany do wielu naukowych ośrodków zagranicznych (do Bari, Rzymu, Mediolanu, Berlina, Bratysławy, Monachium, Lundu, Chicago, Orchard Lake, Waszyngtonu, Londynu, Oksfordu, Grodna, Kowna, Rygi, Lwowa, Moskwy, Wilna, Petersburga, Budapesztu, Brukseli, Bukaresztu, Lyonu, Paryża, Buenos Aires). Na jego łamach, oprócz patrologów duchownych, wypowiadało się wielu wybitnych starożytników polskich (np.: prof. A. Sadurska, prof. J. Strzelczyk, prof. M. Salamon, prof. M. Dzielska, prof. A. Świderkówna, prof. M. Szarmach, prof. T. Dobrzeniecki, prof. M. Jaczynowska, prof. J. Jundziłł) i zagranicznych (np.: prof. Ch. Kannengiesser z University of Notre Dame USA, prof. N. Cipriani z Instytutu Patrystycznego w Rzymie, prof. Ysabel de Andia z Instytutu „Sources Chrétiennes” z Lyonu, prof. B. Kytzler z Freie Universität z Berlina, prof. R. Brändle z Bazylei, ks. prof. J. Woliński z Paryża, prof. E. Dal Covolo z Salesianum z Rzymu, ks. prof. B. Degórski z Angelicum w Rzymie, prof. Luciana Mirri z Bolonii, prof. Michaela i Klaus Zelezerowie z Instytutu CSEL w Wiedniu i inni), którzy w większości są również jego odbiorcami. Periodykowi patronuje Rada Naukowa, złożona z patrologów, filologów, historyków i zespołu redakcyjnego, która zwoływana kilka razy w roku, kontroluje wydawane prace, zatwierdza każdy przygotowany zeszyt oraz omawia go po opublikowaniu. Należą do niej: ks. prof. dr R. Degórski, ks. prof. F. Drączkowski, ks. prof. A. Eckmann, prof. B. Filarska, prof. M. Kaczmarkowski, ks.

${ }^{26}$ Por. S. Longosz, „Vox Patrum” w Oksfordzie, VoxP 7(1987) z. 12-13, 527-530.

27 Por. „Vox Patrum” u Ojca Świętego Jana Pawta II, VoxP 3(1983) z. 5, s. 495. 
dr hab. S. Longosz, prof. K. Stawecka, dr A. Stępniewska, ks. prof. S. Kowalczyk, ks. prof. bp J. Śrutwa, ks. prof. H. Wójtowicz.

W wydanych w ciągu 19 lat 35 zeszytach ukazało się 35 polskich przekładów dokumentów papieskich, 439 artykułów, 52 polskie przekłady niewielkich pism patrystycznych, 172 recenzje, 176 sprawozdań, 43 zestawy bibliografii podmiotowej, bieżącej lub przedmiotowej, 205 informacji z życia patrystycznego i 20 nekrologów ${ }^{28}$. Zawartość naszego periodyku odnotowywana jest w najważniejszych interesujących patrologów bibliografiach międzynarodowych, m.in. w „Bibliographia Patristica” (red. W. Schneemelcher), w „L'Année Philologique” i w „Bulletin d'information et de liaison” - organie Association Internationale d'Études Patristiques.

Ostatnio zaś, po nowej kategoryzacji polskich czasopism naukowych przez Komitet Badań Naukowych, ,Vox Patrum” został zaliczony do najwyżej notowanych punktowo (7 punktów) czasopism teologicznych. Oto ewidentne i uznane owoce popularyzacyjnej działalności Zakładu.

Tak oto wyglądała realizacja postawionych sobie przez Zakład zadań $\mathrm{w}$ ciągu 30 lat jego istnienia. Jedne $\mathrm{z}$ nich zrealizował $\mathrm{w}$ nadmiarze, inne, zależnie od okoliczności, zmodyfikował lub zaniechał. Oprócz wymienionych wyżej zadań Zakład rozpoczął wstępne prace nad sporządzeniem centralnego katalogu publikacji dotyczących antyku chrześcijańskiego, znajdujących się w bibliotekach polskich. Były one prowadzone przy współpracy z Zakładem Katalogów Centralnej Biblioteki Narodowej w Warszawie, ale ze względu na szczupłość kadry pomocniczej przerwano na razie tę pracę. Planowano też opracowanie Encyklopedii Antyku Chrześcijańskiego przy Zakładzie Leksykograficznym, a której sekretarzem naukowym i odpowiedzialnym za całość pracy koncepcyjnej miał być powołany 30 IX 1977 r. decyzją Senatu Akademickiego KUL ks. S. Longosz ${ }^{29}$, ale lukę tę wypełnił w międzyczasie trzytomowy Dizionario Patristico e di Antichità Cristiane (Roma 1983), a u nas w Polsce w pewnym stopniu Stownik Wczesnochrześcijańskiego Piśmiennictwa pod redakcją J.M. Szymusiaka i M. Starowieyskiego (Poznań 1971).

W ciągu 30 lat istnienia Zakład zajął właściwe miejsce w kulturze polskiej i zwrócił oczy zarówno badaczy, jak i sympatyków antyku chrześcijańskiego na Katolicki Uniwersytet Lubelski. Jako pierwszy w okresie powojennym zaczął organizować polskie życie patrystyczne, gromadzić na spotkaniach polskich badaczy starożytności chrześcijańskiej i nawiązywać kontakty z zagranicznymi ośrodkami naukowymi, przyczyniając się m. in. w dużym stopniu również do powstania Sekcji Patrystycznej przy Komisji Episkopatu ds. Nauki Katolickiej, erygowanej w Lublinie 3 listopada 1977 r. na ogólnopolskim sympozjum za-

28 Por. M. Daniluk, Index „Vox Patrum” 1(1981) - 12(1992), VoxP 16(1996) z. 30-31, 541-603.

29 Por. list Rektora KUL nr 633/77/R z dnia 7 X 1977 r. do ks. bpa Ablewicza z prośbą o wyrażenie zgody na jego zatrudnienie. 
kładowym. Patrząc z perspektywy na 30-letnią działalność tego Zakładu, można chyba powiedzieć, że mimo tak małego personelu oraz ciągłych kłopotów lokalowych i finansowych, zajmuje on już trwałe i niepodważalne miejsce w kulturze polskiej, a zwłaszcza wśród badaczy problematyki starożytnego chrześcijaństwa.

\section{IL CENTRO DEGLI STUDI SULL' ANTICHITÀ CRISTIANA ALLA CATTOLICA UNIVERSITÀ DI LUBLIN IN POLONIA (nel 30 anniversario della fondazione)}

\section{(Riasunto)}

L'autore nella prima parte del articolo espone la attuale struttura del Centro (le autorità, le persone lavoratori, la biblioteca, il posto del lavoro scientifico), nella seconda invece parte raccoglie $i$ frutti della sua trentenne attività scientifica sui 7 piani (coordinare gli studi sull' antichità cristiana in Polonia - 30 nazionali conferenze patristiche, rianimare gli studi polacchi sull' archeologia e l'arte paleocristiana, elaborare la polacca bibliografia patristica, raccogliere la bibliografia di „voces”, annodare i contatti e collaborazione con altri centri patristici nazionali e stranieri, propagare il pensiero dei Padri con diversi modi - per le conferenze, le pubblicazioni e il periodico „Vox Patrum” - già 35 volumi). 